\title{
The possible contribution of the periodic emissions from farmers' activities in the North China Plain to atmospheric water-soluble ions in Beijing
}

\author{
Pengfei Liu ${ }^{1,2}$, Chenglong Zhang ${ }^{1,2}$, Yujing Mu ${ }^{1,2,3}$, Chengtang Liu ${ }^{1,2}$, Chaoyang Xue ${ }^{1,2}$, Can Ye ${ }^{1,2}$, Junfeng Liu ${ }^{1,2}$, \\ Yuanyuan Zhang ${ }^{1,2}$, and Hongxing Zhang ${ }^{1,4}$ \\ ${ }^{1}$ Research Center for Eco-Environmental Sciences, Chinese Academy of Sciences, Beijing, 100085, China \\ ${ }^{2}$ University of Chinese Academy of Sciences, Beijing, 100049, China \\ ${ }^{3}$ Center for Excellence in Urban Atmospheric Environment, Institute of Urban Environment, Chinese Academy of Sciences, \\ Xiamen, 361021, China \\ ${ }^{4}$ Beijing Urban Ecosystem Research Station, Beijing, 100085, China
}

Correspondence to: Yujing Mu (yjmu@rcees.ac.cn)

Received: 26 January 2016 - Published in Atmos. Chem. Phys. Discuss.: 16 March 2016

Revised: 22 July 2016 - Accepted: 22 July 2016 - Published: 11 August 2016

\begin{abstract}
The North China Plain (NCP), which includes Beijing, is currently suffering from severe haze events due to a high pollution level of $\mathrm{PM}_{2.5}$. To mitigate the serious pollution problem, identification of the sources of $\mathrm{PM}_{2.5}$ is urgently needed for the effective control measures. Daily samples of $\mathrm{PM}_{2.5}$ were collected in Beijing city and in a rural area in Baoding, Hebei Province through the year of 2014, and the seasonal variation of water-soluble ions (WSIs) in $\mathrm{PM}_{2.5}$ was comprehensively analysed to determine their possible sources. The results indicated that the periodic emissions from farmers' activities made a significant contribution to the atmospheric WSIs in Beijing. The relatively high concentration of $\mathrm{K}^{+}$in winter and autumn at the two sampling sites confirmed that crop straw burning contributed to atmospheric $\mathrm{K}^{+}$in Beijing. The remarkable elevation of $\mathrm{Cl}^{-}$at the two sampling sites as well as the evident increase of the $\mathrm{Cl}^{-} / \mathrm{K}^{+}$ratio and the $\mathrm{Cl}^{-}$proportion in WSIs during the winter in Beijing could be ascribed to coal combustion for heating by farmers. The unusually high ratio of $\mathrm{Cl}^{-}$to $\mathrm{Na}^{+}$in summer, the obviously high concentrations of $\mathrm{Cl}^{-}$in the rural sampling site and the elevation of $\mathrm{Cl}^{-}$proportion in WSIs in Beijing during the maize fertilization could be explained by the use of the prevailing fertilizer of $\mathrm{NH}_{4} \mathrm{Cl}$ in the vast area of NCP. The abnormally high concentrations of $\mathrm{Ca}^{2+}$ at the two sampling sites and the elevation of $\mathrm{Ca}^{2+}$ proportion during the period of the maize harvest and soil ploughing
\end{abstract}

in Beijing provided convincing evidence that the intensive agricultural activities in autumn contributed to the regional mineral dust. The most serious pollution episodes in autumn were coincident with significant elevation of $\mathrm{Ca}^{2+}$, indicating that the mineral dust emission from the harvest and soil ploughing not only increased the atmospheric concentrations of the primary pollutants, but also greatly accelerated formation of sulfate and nitrate through heterogeneous reactions of $\mathrm{NO}_{2}$ and $\mathrm{SO}_{2}$ on the mineral dust. The backward trajectories also indicated that the highest concentrations of WSIs usually occurred in the air parcel from southwest-south regions, which have a high density of farmers. In addition, the values of nitrogen oxidation ratio (NOR) and the sulfur oxidation ratio (SOR) were found to be much greater under haze days than under non-haze days, implying that formation of sulfate and nitrate was greatly accelerated through heterogeneous or multiphase reactions of $\mathrm{NO}_{2}$ and $\mathrm{SO}_{2}$ on $\mathrm{PM}_{2.5}$.

\section{Introduction}

The North China Plain (NCP) is frequently suffering from severe haze pollution in recent years (Chan and Yao, 2008; Liang et al., 2016), which has aroused great attention from the general public (Zhang et al., 2014; Guo et al., 2014; R. J. Huang et al., 2014; Y. R. Yang et al., 2015; Y.-L. Zhang 
et al., 2015; G. J. Zheng et al., 2015; Sun et al., 2006). The severe haze pollution is mainly ascribed to elevation of fine particulate matter with dynamic diameter less than $2.5 \mu \mathrm{m}$ $\left(\mathrm{PM}_{2.5}\right)$ (R. J. Huang et al., 2014). $\mathrm{PM}_{2.5}$ can directly reduce atmospheric visibility by scattering or absorbing solar light (Seinfeld and Pandis, 1998; Buseck and Posfai, 1999; Cheng et al., 2006) and is harmful to human health (Finlayson-Pitts and Pitts, 2000; Nel, 2005; Pöschl, 2005; Peplow, 2014).

To mitigate the serious pollution problem, identification of the sources of $\mathrm{PM}_{2.5}$ is urgently needed for the effective control measures. Based on field measurements, positive matrix factorization (PMF) (Yu et al., 2013; Wu et al., 2014; R. J. Huang et al., 2014), principal component analysis (PCA) (Wang et al., 2015) and chemical mass balance (CMB) (R. J. Huang et al., 2014; Guo et al., 2012) have been widely used for identifying the sources of $\mathrm{PM}_{2.5}$. However, the results of the source apportionment are still not convincing because there are large uncertainties about the indicators, dominant factors and emission inventories used for the identification. For example, some studies suggested traffic emissions in Beijing contributed about $15-20 \%$ to the $\mathrm{PM}_{2.5}(\mathrm{Yu}$ et al., 2013; Wu et al., 2014), while only $4 \%$ of the contribution was also reported (Zhang et al., 2013). Additionally, the current source apportionment can only present gross contribution of each source classification, but there are markedly different emissions from individual sources in the same classification. For example, due to the strict control measures and highly efficient combustion, the emissions of pollutants from power plants and big boilers fuelled by coal must be totally different from the emissions of farmers' coal stoves in both the emission intensity and composition of pollutants. Finally, most studies about source apportionment mainly focused on emissions from traffic, industry, construction and secondary formation, whereas the emissions from farmers' activities in the NCP were often neglected.

There are about $300000 \mathrm{~km}^{2}$ of agricultural fields and 0.16 billion farmers in the NCP (Zhang et al., 2011). The farmers' activities in the NCP are seasonal, e.g. the fertilization events and harvests mainly occur in June-July and OctoberNovember and farmers' coal stoves are prevailingly used for heating in winter. The seasonal activities of farmers in the NCP were suspected to make significant contribution to deteriorate the regional air quality, e.g. the most serious pollution events (or haze days) in the NCP were usually coincident with the three seasonal activities of farmers in recent years (Y. R. Yang et al., 2015; Huang et al., 2012; Li et al., 2014; Li et al., 2011; Liu et al., 2013; Sun et al., 2013). The serious pollution events during harvest seasons were widely ascribed to crop straw burning (Huang et al., 2012; Li et al., 2014), but the influence of fertilization events and crop straw returning to fields on the regional air quality during the harvest season periods was mostly neglected. Strong ammonia $\left(\mathrm{NH}_{3}\right)$ emission from the vast agricultural fields in the NCP has been found during fertilization events just after the wheat harvest (in June-July) (Zhang et al., 2011), which must acceler- ate atmospheric ammonium formation. Although crop straws burning by stealth is still prevalent, most residual crops are being returned into the agricultural fields under the advocacy of government for protecting the air quality. Because crop leaves absorbed large quantities of atmospheric particles during crop growing season (Bealey et al., 2007; Ji et al., 2013), the abrupt release of the particles by smashing crop straw for returning in the vast area of the NCP must also make a contribution to atmospheric particles in the region during the seasonal harvest seasons. In winter, heavy smoke from the chimneys of the farmers' coal stoves can be seen everywhere in rural areas of the NCP due to heating supply. Although residential coal consumption only accounts for a small fraction of the total, e.g. $\sim 11 \%$ in Beijing-Tianjin-Hebei area (http:// hbdczx.mep.gov.cn/pub/), the emission factors of typical pollutants such as $\mathrm{PM}_{2.5}$, organic carbon (OC) and polycyclic aromatic hydrocarbons (PAHs) from farmers' coal stoves (about $1054-12910 \mathrm{mg} \mathrm{kg}^{-1}$ for $\mathrm{PM}_{2.5}, 470-7820 \mathrm{mg} \mathrm{kg}^{-1}$ for OC and 58.5-229.1 $\mathrm{mg} \mathrm{kg}^{-1}$ for PAHs) are usually about 1-3 orders of magnitude greater than those from coal power plants or industry boilers (about $16-100 \mathrm{mg} \mathrm{kg}^{-1}$ for $\mathrm{PM}_{2.5}$, $0.3-17.1 \mathrm{mg} \mathrm{kg}^{-1}$ for OC and $0.8-12.8 \mu \mathrm{g} \mathrm{kg}^{-1}$ for PAHs) (Zhang et al., 2008; Xu et al., 2006; Geng et al., 2014; Chen et al., 2005; Revuelta et al., 1999; Yang et al., 2016), and the coal consumption by farmers mainly concentrates on the 4 months in winter.

In this study, to understand the possible influence of farmers' activities on the regional air quality in the NCP, filter samples of $\mathrm{PM}_{2.5}$ were collected daily in Beijing city as well as a rural area in Baoding, Hebei Province for a whole year of 2014, and the seasonal variation characteristics of the watersoluble ions (WSIs) in the $\mathrm{PM}_{2.5}$ samples were comprehensively investigated in relation to the farmers' activities. The scientific evidence found in this study will be helpful for future control measures in reducing pollutant emissions from rural areas in the NCP.

\section{Materials and methods}

\subsection{Sampling sites}

The sampling site in Beijing city was on a rooftop (about $25 \mathrm{~m}$ above ground) in the Research Center for Eco-Environmental Sciences (here referred to as RCEES, $40^{\circ} 00^{\prime} 29.85^{\prime \prime} \mathrm{N}, 116^{\circ} 20^{\prime} 29.71^{\prime \prime} \mathrm{E}$ ), which is located between the north fourth-ring road and the north fifth-ring road of Beijing and surrounded by some institutes, campuses, and residential areas (Pang and $\mathrm{Mu}, 2006$ ). Another sampling site in a rural area was selected on the rooftop of a field station (about $5 \mathrm{~m}$ above ground) which is located in the agricultural field of Dongbaituo village (here referred to as DBT, $38^{\circ} 39^{\prime} 37.36^{\prime \prime} \mathrm{N}, 115^{\circ} 15^{\prime} 16.05^{\prime \prime}$ E), Baoding, Hebei Province. The rural sampling site is far away from industries, traffic and commercial emissions. The distance between the 


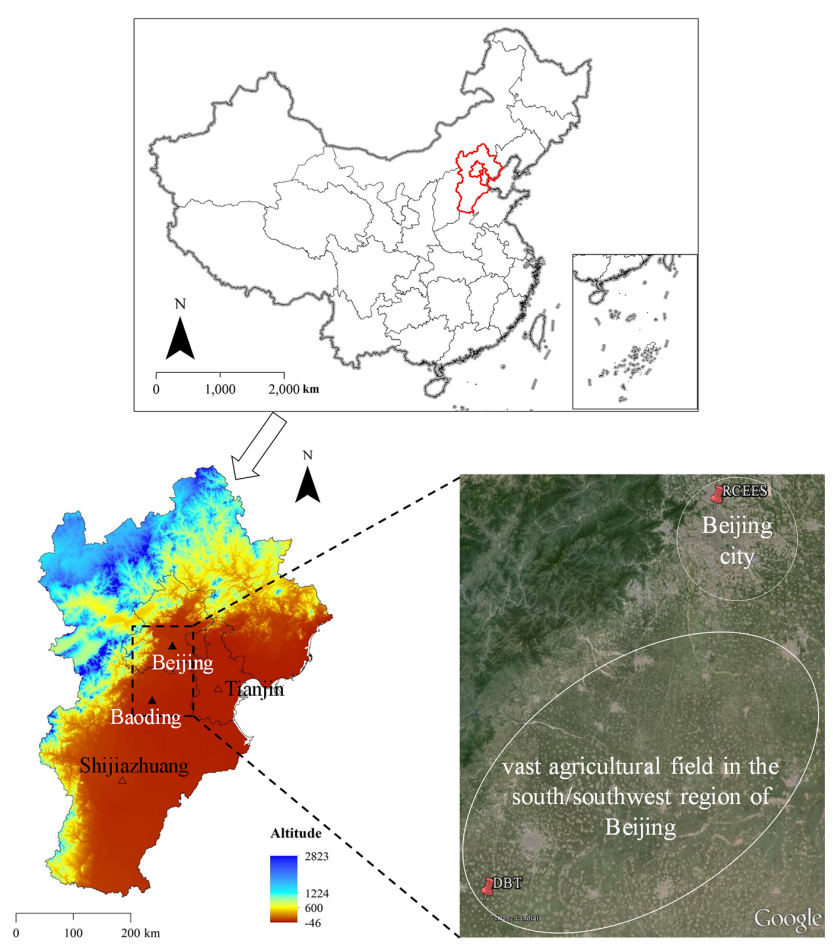

Figure 1. Sampling sites (the urban site in Beijing city and the rural site in Baoding, Hebei Province) in the NCP.

two sampling sites is about $170 \mathrm{~km}$ and the detailed location of the two sampling sites is presented in Fig. 1.

\subsection{Sample collection}

$\mathrm{PM}_{2.5}$ samples at the two sites were both collected on Millipore PTFE filters $\left(90 \mathrm{~mm}\right.$ ) by a $\mathrm{PM}_{2.5}$ sampler (LaoYing2034) and the sampling flow rate was set to $100 \mathrm{~L} \mathrm{~min}^{-1}$. The duration of each sampling was $24 \mathrm{~h}$, starting at 03:00 p.m. every day and ending at 03:00 p.m. (UTC +8$)$ on the next day. All the samples were put in dedicated filter storage containers (90 $\mathrm{mm}$, Millipore) after sampling and preserved in a refrigerator till analysis. For the sampling site of RCEES, a total of $235 \mathrm{PM}_{2.5}$ samples were collected from January to November of 2014, in winter (9 January-15 March), spring (16 March-31 May), summer (1-30 June, 9-21 August) and autumn (19 September-14 November). To explore the possible influence of farmers' activities, $\mathrm{PM}_{2.5}$ samples at DBT were mainly collected during the periods of periodic farmers' activities: heating season in winter (9 January-25 February), harvest seasons in summer (9-22 June, 9-17 August) and autumn (19 September-18 October, 28 October-14 November).

\subsection{Sample analysis}

Each sample filter was extracted ultrasonically with $10 \mathrm{~mL}$ ultrapure water for half an hour. The solutions were fil-
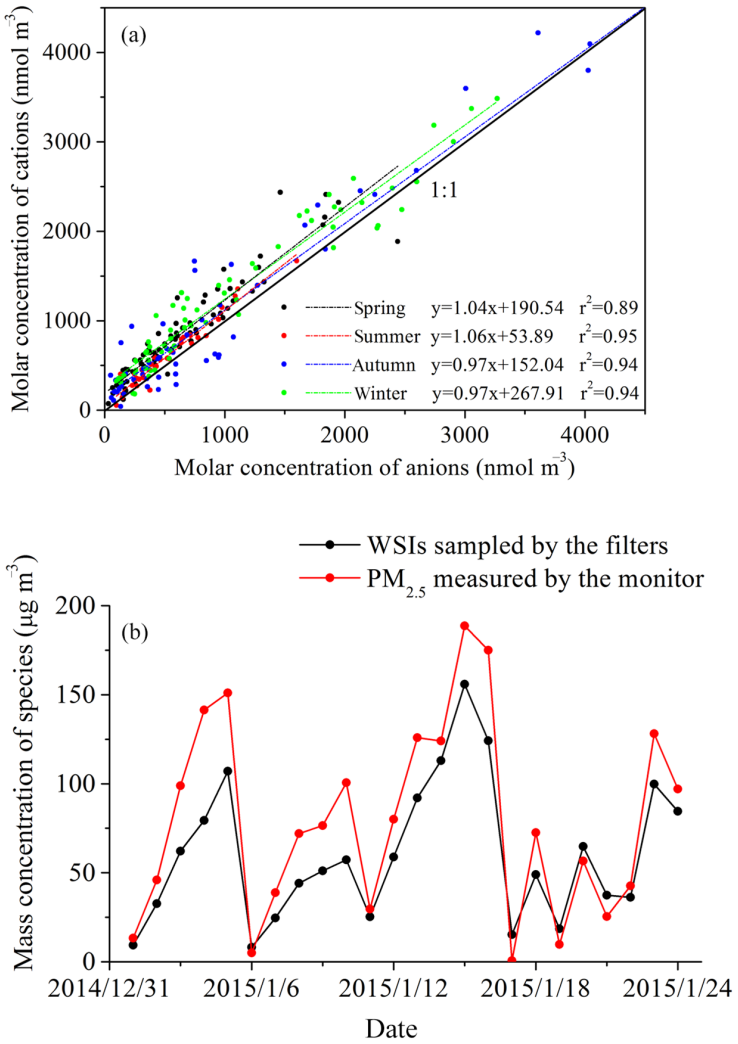

Figure 2. The ratios of cations to anions in the four seasons of 2014 in Beijing (a), and the comparison between WSIs sampled by the filters and $\mathrm{PM}_{2.5}$ measured by the TEOM monitor (b, 1-24 January 2015).

tered through a micro-porous membrane (pore size, $0.45 \mu \mathrm{m}$; diameter, $13 \mathrm{~mm}$ ) before analysis and the WSIs in the treated filtrates were analysed by Ion Chromatography (IC, WAYEE IC6200). Five anions $\left(\mathrm{F}^{-}, \mathrm{HCOO}^{-}, \mathrm{Cl}^{-}, \mathrm{NO}_{3}^{-}\right.$and $\mathrm{SO}_{4}^{2-}$ ) were separated by using an anion column (IC SI$524 \mathrm{E}, 4 \mathrm{mmID} \times 250 \mathrm{~mm})$ with the eluent $\left(3.6 \mathrm{mmol} \mathrm{L}^{-1}\right.$ $\mathrm{Na}_{2} \mathrm{CO}_{3}$ ) flow rate of $0.8 \mathrm{~mL} \mathrm{~min}^{-1}$ and column temperature of $45^{\circ} \mathrm{C}$. Five cations $\left(\mathrm{Na}^{+}, \mathrm{NH}_{4}^{+}, \mathrm{Mg}^{2+}, \mathrm{Ca}^{2+}\right.$ and $\left.\mathrm{K}^{+}\right)$ were separated by using a cation column (TSKgelSuperIC$\mathrm{CR}, 4.6 \mathrm{mmID} \times 15 \mathrm{~cm})$ with the eluent $\left(2.2 \mathrm{mmol} \mathrm{L}^{-1} \mathrm{MSA}\right.$ and $1 \mathrm{mmol} \mathrm{L}^{-1} 18$-crown-6) flow rate of $0.7 \mathrm{~mL} \mathrm{~min}^{-1}$ and column temperature of $40^{\circ} \mathrm{C}$. The relative standard deviation (RSD) of each ion was less than $0.5 \%$ for the reproducibility test. The detection limits $(S / N=3)$ were less than $0.001 \mathrm{mg} \mathrm{L}^{-1}$ for the anions and cations. At least three filter blanks were analysed for 60 filter samples, and the average blank values were about $0.03 \mathrm{mg} \mathrm{L}^{-1}$ for $\mathrm{Na}^{+}, \mathrm{Ca}^{2+}, \mathrm{F}^{-}$, $\mathrm{NO}_{3}^{-}$and $\mathrm{SO}_{4}^{2-}, 0.02 \mathrm{mg} \mathrm{L}^{-1}$ for $\mathrm{NH}_{4}^{+}$and $\mathrm{Cl}^{-}, 0.01 \mathrm{mg} \mathrm{L}^{-1}$ for $\mathrm{Mg}^{2+}, \mathrm{K}^{+}$and $\mathrm{HCOO}^{-}$. The concentrations of all the ions were corrected for blanks. 


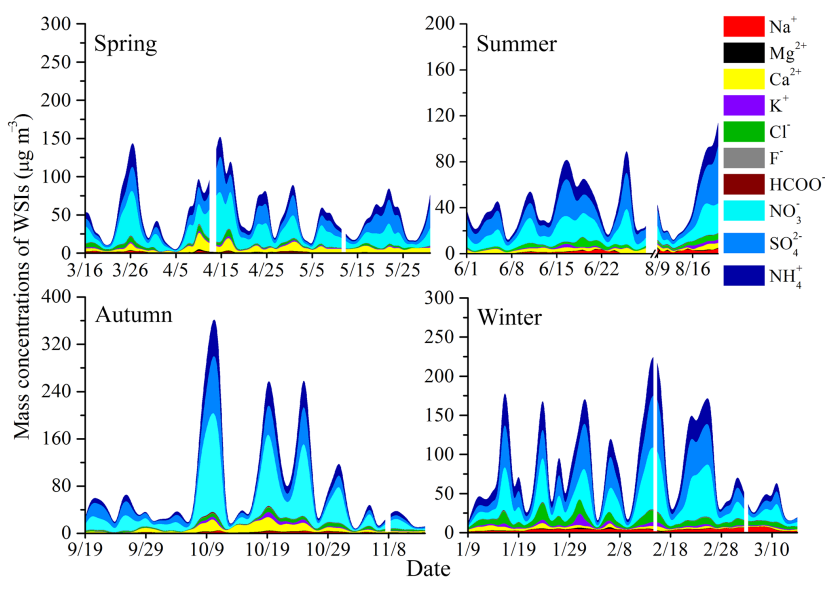

Figure 3. Variation of WSIs in each season at RCEES (the smooth lines for the WSIs were drawn between the points of the daily data.).

\subsection{Meteorology, trace gases and back trajectory}

The meteorological data, including temperature, wind speed, wind direction, relative humidity $(\mathrm{RH})$, visibility and air pollution index of $\mathrm{PM}_{2.5}, \mathrm{SO}_{2}, \mathrm{NO}_{2}, \mathrm{O}_{3}$ at RCEES were from Beijing urban ecosystem research station (http://www. bjurban.rcees.cas.cn/ ), which is about $20 \mathrm{~m}$ away from our sampling site of RCEES.

To identify the potential influence of air parcel transport, the air mass backward trajectories were calculated for $72 \mathrm{~h}$ through the Hybrid Single-Particle Lagrangian Integrated Trajectory (HYSPLIT 4) Model of the Air Resources Laboratory of NOAA with NCEP Final analyses data. The backward trajectories arriving at $500 \mathrm{~m}$ above sampling position were computed at 00:00, 06:00, 12:00 and 18:00 (UTC) in each sampling day, respectively. A total of 940 backward trajectories with 72 hourly trajectory endpoints in four seasons were used as input for further analysis.

\section{Results and discussion}

The ratios of total cation concentration (defined as $\left.\left[\mathrm{Na}^{+}\right]+\left[\mathrm{NH}_{4}^{+}\right]+2 \times\left[\mathrm{Mg}^{2+}\right]+2 \times\left[\mathrm{Ca}^{2+}\right]+\left[\mathrm{K}^{+}\right]\right)$to total anion concentration (defined as $\left[\mathrm{F}^{-}\right]+\left[\mathrm{HCOO}^{-}\right]+$ $\left.\left[\mathrm{Cl}^{-}\right]+\left[\mathrm{NO}_{3}^{-}\right]+2 \times\left[\mathrm{SO}_{4}^{2-}\right]\right)$ in different seasons are illustrated in Fig. 2a. The near unity of the ratios indicated excellent charge balance in $\mathrm{PM}_{2.5}$ and high quality of the data. The mass concentrations of WSIs and $\mathrm{PM}_{2.5}$ at the sampling site of RCEES during the period of 1-24 January 2015 were also simultaneously measured by the filter sampling method and the TEOM 1405 Monitor, respectively. As shown in Fig. 2b, the variation trends of the WSIs and $\mathrm{PM}_{2.5}$ were almost the same with a correlation coefficient $\left(R^{2}\right)$ of 0.91 , implying that the concentration of WSIs measured could be used as an indicator of the pollution level. The average mass concentration of WSIs contributed about $80 \%$ to the mass of

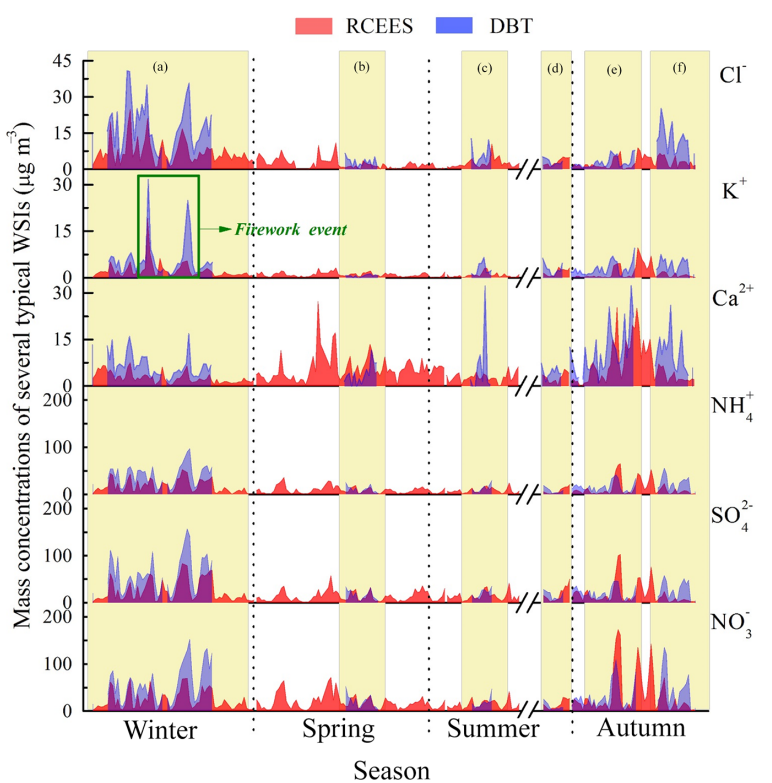

Figure 4. Concentrations of selected WSIs in the year of 2014. (The mass concentrations of $\mathrm{Cl}^{-}, \mathrm{K}^{+}, \mathrm{Ca}^{2+}, \mathrm{NH}_{4}^{+}, \mathrm{SO}_{4}^{2-}$ and $\mathrm{NO}_{3}^{-}$ were presented at RCEES and DBT. The green square shows the firework event during the period of the Spring Festival. The areas shaded in yellow represent farmers' activities, including residential coal combustion for heating (a), top dressing for wheat (b), wheat harvest and basal fertilization for maize (c), top dressing for maize (d), maize harvest and soil ploughing (e) and straw burning (f).)

$\mathrm{PM}_{2.5}$ measured by the TEOM 1405 Monitor, which was much greater than the values of 50-60\% reported by previous studies in the NCP (Shen et al., 2009; Li et al., 2013). It was possible that the mass concentration of $\mathrm{PM}_{2.5}$ measured by the TEOM 1405 Monitor was underestimated because the volatile even semi-volatile component in $\mathrm{PM}_{2.5}$ can be easily lost at $50^{\circ} \mathrm{C}$ which is designed in the TEOM 1405 Monitor for avoiding water condensation on the filter (Charron et al., 2004; Grover et al., 2005; C. N. Liu et al., 2014). It is well documented that temperature is a key factor affecting the distribution of $\mathrm{NH}_{4} \mathrm{NO}_{3}$ on particle phase due to its thermal decomposition, e.g. at a temperature greater than $35^{\circ} \mathrm{C}$, little $\mathrm{NH}_{4} \mathrm{NO}_{3}$ is expected under typical ambient conditions (Finlayson-Pitts and Barbara, 1986). The total mass proportions of $\mathrm{NO}_{3}^{-}$and $\mathrm{NH}_{4}^{+}$in WSIs usually account for about $50 \%$ in Beijing city (Y. Yang et al., 2015), whereas they were found to only account for about $20 \%$ in the filters of the TEOM 1405 Monitor in this study, confirming the serious loss of $\mathrm{NH}_{4} \mathrm{NO}_{3}$ under the high temperature adopted by the TEOM 1405 Monitor.

\subsection{Daily variations of WSIs in Beijing city}

The daily variation of WSIs at RCEES in each season is illustrated in Fig. 3 and the average mass concentrations of the 
Table 1. Concentrations $\left(\mu \mathrm{g} \mathrm{m}^{-3}\right.$ ) of the WSIs (mean concentrations and standard deviation (SD)) in four seasons at RCEES.

\begin{tabular}{|c|c|c|c|c|c|c|c|c|c|c|}
\hline \multirow[t]{2}{*}{ Species } & \multicolumn{2}{|c|}{ Spring $(N=74)$} & \multicolumn{2}{|c|}{ Summer $(N=41)$} & \multicolumn{2}{|c|}{ Autumn $(N=56)$} & \multicolumn{2}{|c|}{ Winter $(N=64)$} & \multicolumn{2}{|c|}{ Annual $(N=235)$} \\
\hline & Mean & SD & Mean & SD & Mean & SD & Mean & SD & Mean & $\mathrm{SD}$ \\
\hline $\mathrm{F}^{-}$ & 0.3 & 0.3 & 0.2 & 0.1 & 0.4 & 0.2 & 0.2 & 0.2 & 0.3 & 0.2 \\
\hline $\mathrm{HCOO}^{-}$ & 0.2 & 0.1 & 0.2 & 0.1 & 0.4 & 0.5 & 0.3 & 0.2 & 0.3 & 0.3 \\
\hline $\mathrm{Cl}^{-}$ & 2.4 & 2.2 & 2.6 & 1.9 & 2.8 & 2.3 & 7.0 & 4.9 & 3.9 & 3.7 \\
\hline $\mathrm{NO}_{3}^{-}$ & 18.4 & 16.0 & 13.4 & 9.3 & 34.3 & 45.2 & 23.8 & 22.8 & 22.8 & 27.7 \\
\hline $\mathrm{SO}_{4}^{2-}$ & 13.0 & 10.9 & 14.6 & 11.6 & 18.1 & 22.8 & 22.2 & 19.6 & 17.0 & 17.3 \\
\hline $\mathrm{Na}^{+}$ & 1.2 & 0.8 & 2.1 & 1.4 & 1.6 & 1.1 & 3.8 & 1.7 & 2.3 & 1.8 \\
\hline $\mathrm{NH}_{4}^{+}$ & 8.8 & 7.4 & 7.6 & 6.0 & 12.3 & 16.3 & 16.5 & 13.6 & 11.5 & 12.2 \\
\hline $\mathrm{Mg}^{2+}$ & 0.5 & 0.4 & 0.3 & 0.2 & 0.4 & 0.3 & 0.5 & 0.5 & 0.4 & 0.4 \\
\hline $\mathrm{Ca}^{2+}$ & 5.6 & 4.2 & 2.9 & 1.5 & 6.8 & 6.4 & 2.6 & 1.8 & 4.6 & 4.4 \\
\hline $\mathrm{K}^{+}$ & 1.0 & 0.7 & 1.1 & 1.0 & 1.6 & 2.2 & 2.2 & 2.7 & 1.5 & 1.9 \\
\hline Mass & 50.5 & 37.3 & 44.2 & 28.9 & 78.3 & 92.6 & 78.7 & 61.2 & 63.7 & 62.0 \\
\hline
\end{tabular}
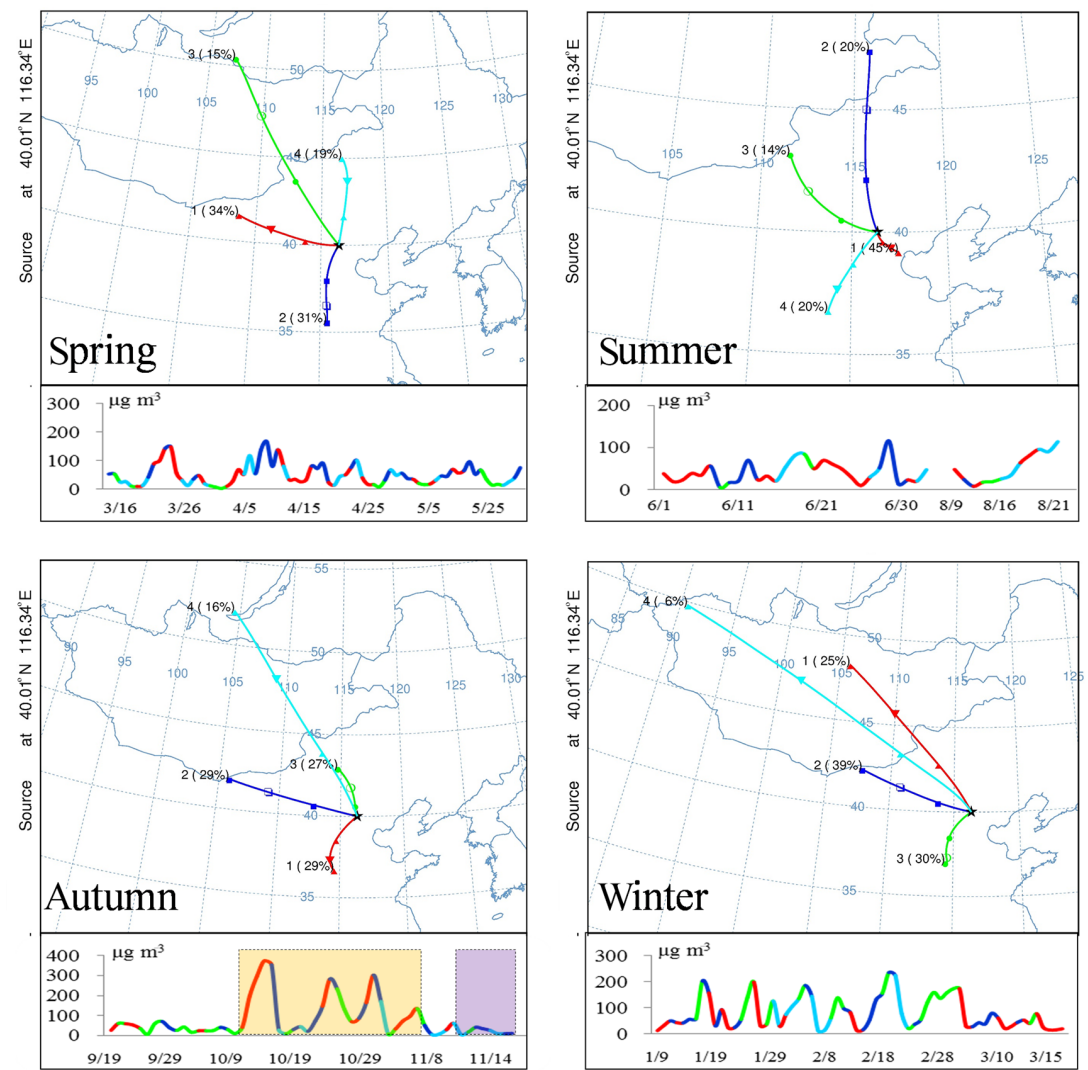

Figure 5. The back trajectory cluster analysis and the corresponding overall ion mass concentration during the four seasons in Beijing. (The area shaded in yellow represents the period with the high concentrations of $\mathrm{Ca}^{2+}$ both at RCEES and DBT. The area shaded in purple represents the period with the high concentrations of $\mathrm{Ca}^{2+}$ at DBT but the low concentrations of $\mathrm{Ca}^{2+}$ at RCEES (See Fig. 4).)

WSIs at RCEES are summarized in Table 1. It is evident that the concentration of the WSIs varied greatly on a timescale of days, indicating meteorological conditions played a pivotal role in accumulation and dissipation of atmospheric pollutants. For example, the highest frequency pollution levels of the WSIs in winter were mainly ascribed to the relatively sta- ble meteorological conditions with the low height of boundary layer which favoured pollutants' accumulation (Wang et al., 2013; Quan et al., 2014; Tian et al., 2014; Wang et al., 2014; L. Zhang et al., 2015). Besides meteorological conditions, the extremely high levels of the WSIs during the pollu- 
tion episodes revealed strong sources of the pollutants around Beijing.

The mean concentrations $\left(\mu \mathrm{g} \mathrm{m}^{-3}\right)$ of WSIs at RCEES in spring, summer, autumn and winter were $50.5 \pm 37.3$, $44.2 \pm 28.9,78.3 \pm 92.6$, and $78.7 \pm 61.2$, respectively. $\mathrm{NO}_{3}^{-}, \mathrm{SO}_{4}^{2-}$ and $\mathrm{NH}_{4}^{+}$were found to be the principal ions, accounted for about $80 \%$ of the total WSIs in each season, which were in line with previous studies (Hu et al., 2014; Y. Yang et al., 2015; Huang et al., 2016; Y. R. Yang et al., 2015). The three principal ions were mainly ascribed to secondary formation as discussed in the following section. Although the most intensive photochemical reactivity in summer favours sulfate and nitrate formation, the relatively low $\mathrm{SO}_{2}$ concentration, the reduced gas-to-particle partitioning of ammonium nitrate and the frequent scavenging by rain events must greatly counteract the contribution of the secondary formation, resulting in the lowest pollution levels of the WSIs in summer. In comparison with other seasons, the large elevation of atmospheric $\mathrm{SO}_{2}$ and $\mathrm{NO}_{x}$ (see Sect. 3.2.3) in winter would result in large sulfate and nitrate formation rates despite the lower concentrations of oxidizing species and cause the highest mean concentration of WSIs. Although the atmospheric concentrations of $\mathrm{SO}_{2}$ and $\mathrm{NO}_{x}$ in autumn were much smaller than in winter and in spring (see Sect. 3.2.3), the mean concentration of WSIs in autumn was almost the same as that in winter and nearly twice as those in spring and summer, indicating that special mechanisms dominated the secondary formation of the atmospheric principal ions (see Sect. 3.2.3).

\subsection{The possible sources for the WSIs}

To explore the possible contribution of the periodic emissions from farmers' activities to the WSIs in Beijing, the concentrations of typical WSIs at the urban and rural sites are compared in Fig. 4. It is evident that the seasonal variation of the typical WSIs at the two sites exhibited the similar trend, indicating the similar regional meteorological conditions. The concentrations of the typical WSIs at DBT were generally higher than those at RCEES during the periods of farmers' activities (heating in winter, fertilization in summer and maize harvest in autumn). To reveal the air mass transport influence on the WSIs in Beijing, 3-day backward trajectories for clusters and the corresponding mass concentrations of WSIs during the four seasons in Beijing were analysed, and the results are illustrated in Fig. 5. It could be seen that the highest concentrations of the typical WSIs were usually observed in the air parcels from southwest-south regions with high density of population. Considering the large fraction $(\sim 30 \%)$ of air parcels from the southwest-south regions in each season, the human activities in the southwest-south regions contributed to the atmospheric WSIs in Beijing. Besides the industries, the emissions from the high density of farmers in the southwest-south regions of Beijing was also suspected to affect the atmospheric WSIs in Beijing.
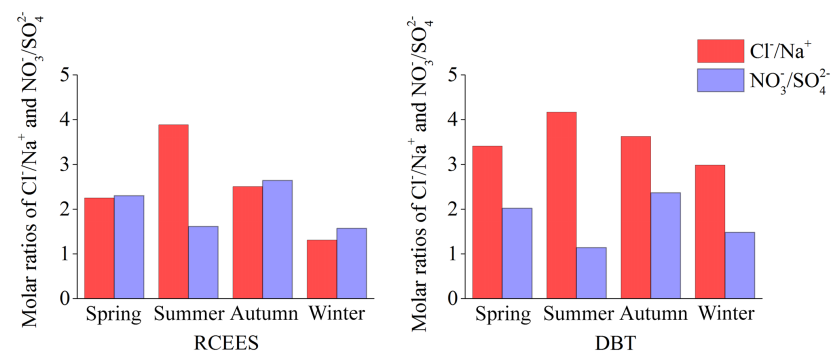

Figure 6. The average molar ratios of $\mathrm{Cl}^{-} / \mathrm{Na}^{+}$and $\mathrm{NO}_{3}^{-} / \mathrm{SO}_{4}^{2-}$ in each season at the two sites.

\subsubsection{The sources of $\mathrm{K}^{+}$and $\mathrm{Cl}^{-}$}

With the exception of the extremely high concentrations of $\mathrm{K}^{+}$on 1 and 16 February (Fig. 4) due to fireworks for celebrating Spring Festival and Lantern Festival (Jiang et al., 2015; Kong et al., 2015), the concentrations of $\mathrm{Cl}^{-}$and $\mathrm{K}^{+}$ were much higher in winter and autumn than in spring and summer at the two sites (Fig. 4). The molar ratio of $\mathrm{Cl}^{-}$ to $\mathrm{Na}^{+}$at the two sites measured by this study (Fig. 6) in each season was above 1.30 which was greater than the value of 1.18 in fresh sea-salt particles (Brewer, 1975), indicating sources other than sea-salt dominated atmospheric $\mathrm{Cl}^{-}$. The pronounced correlation coefficients $(r>0.6, p<0.01)$ between $\mathrm{K}^{+}$(the indicator for biomass burning, Gao et al., 2011) and $\mathrm{Cl}^{-}$in winter and autumn indicated that crop straw burning was a common source for $\mathrm{K}^{+}$and $\mathrm{Cl}^{-}$( $\mathrm{Li}$ et al., 2014). However, only crop straw burning could not explain the relatively high concentrations of $\mathrm{Cl}^{-}$in winter (Fig. 4), because the average molar $\mathrm{Cl}^{-} / \mathrm{K}^{+}$ratio of 7.8 (except for firework events during the Spring Festival) in winter was about a factor of 2 greater than the value of 4.2 in autumn when straw burning prevailed in the region. Besides straw burning and sea-salt, coal combustion (Yu et al., 2013; Wu et al., 2014) and biofuel burning (Christian et al., 2010) have been also recognized as the sources for atmospheric $\mathrm{Cl}^{-}$. Coal have almost been replaced with natural gas and electricity for heating during the winter before 2013 in Beijing city (Ma et al., 2015). Considering the relatively stable $\mathrm{Cl}^{-}$emissions from coal combustion of industries and power plants as well as biofuel burning during the whole year, the obviously higher $\mathrm{Cl}^{-}$concentrations measured in winter than in other seasons (Fig. 4) should be ascribed to the additional coal combustion by farmers because of the large amount of residential coal consumption (about $42 \mathrm{Tg}_{\mathrm{year}}{ }^{-1}$ ) in the Beijing-Tianjin-Hebei region and extremely high emission factors of $\mathrm{Cl}^{-}\left(80-300 \mathrm{mg} \mathrm{kg}^{-1}\right.$ coal) from the coal combustion (W. Huang et al., 2014). The obviously higher $\mathrm{Cl}^{-}$ proportion in winter than in early spring (Fig. 7) provided further evidence for the above conclusion, because the proportion largely counteracted the influence of meteorological factors. 


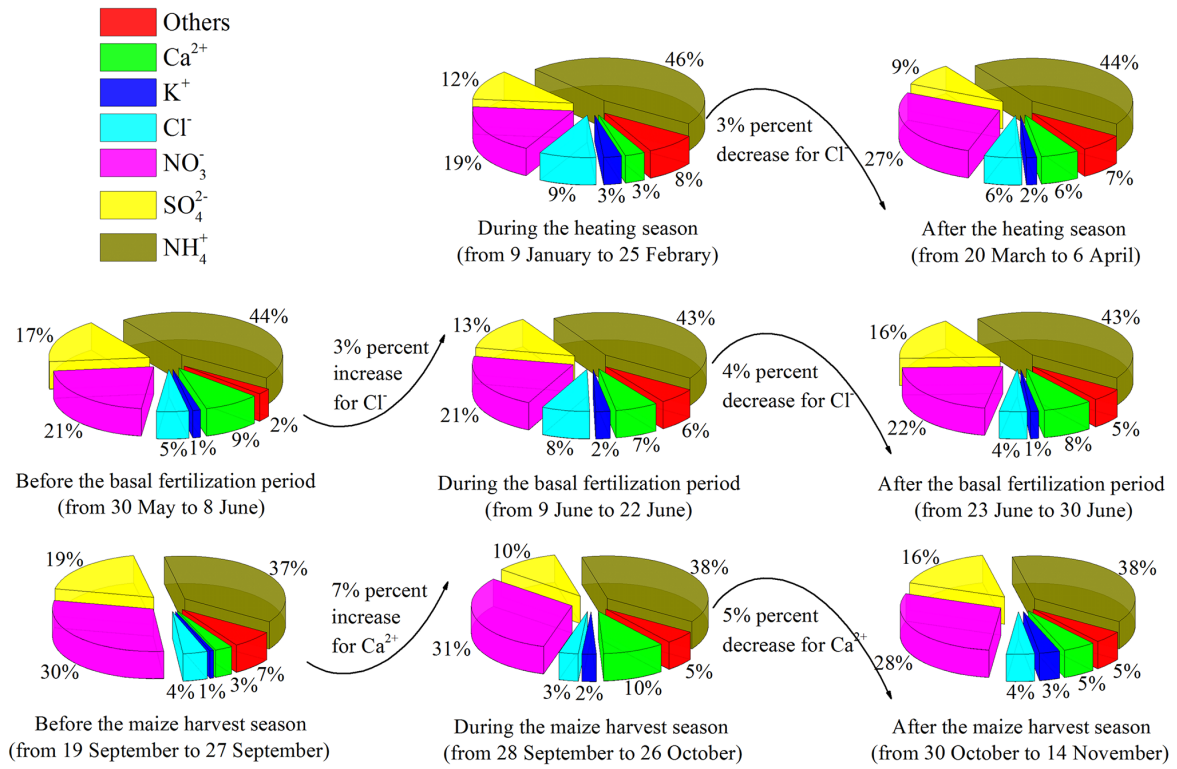

Figure 7. Molar fractions of atmospheric WSIs at RCEES before, during and after the periods of heating in winter, maize fertilization in summer, and maize harvest and soil ploughing in autumn.

It is interesting to note that the remarkably higher $\mathrm{Cl}^{-} / \mathrm{Na}^{+}$ratio was observed in summer than in other seasons at RCEES (Fig. 6), which could not be explained by the $\mathrm{Cl}^{-}$sources mentioned above. Fertilization events in the vast agricultural fields of the NCP were suspected to contribute to atmospheric $\mathrm{Cl}^{-}$in Beijing because volatile $\mathrm{NH}_{4} \mathrm{Cl}$ fertilizer are prevailingly used as the basal fertilization for maize in summer. Based on the yearbook of the China fertilizer industry (2012), national production of $\mathrm{NH}_{4} \mathrm{Cl}$ fertilizers was about $1.174 \mathrm{Tg}$ in 2011 , which was mainly used as the basal fertilization for maize in summer. The obviously high concentrations of $\mathrm{Cl}^{-}$at DBT (Fig. 4) were indeed observed during the basal fertilization period for maize in June. Compared with the periods before and after maize fertilization, the proportion of $\mathrm{Cl}^{-}$during maize fertilization in summer increased about 3-4\% (Fig. 7), confirming the influence of maize fertilization on atmospheric $\mathrm{Cl}^{-}$in Beijing. The extremely high concentration (about $2 \mathrm{ppbv}$ ) of nitryl chloride $\left(\mathrm{ClNO}_{2}\right)$ observed by Tham et al. (2016) at the same rural site in June indirectly indicated the high concentrations of $\mathrm{Cl}^{-}$ during the period of basal fertilization for maize. Because fertilization is an important source for atmospheric $\mathrm{NH}_{3}$, the elevation of $\mathrm{Cl}^{-}$(as a tracer for fertilization) revealed that fertilization in the rural areas around Beijing could also make an obvious contribution to atmospheric $\mathrm{NH}_{4}^{+}$in Beijing.

\subsubsection{The sources of $\mathrm{Ca}^{2+}$}

The remarkably high concentrations of $\mathrm{Ca}^{2+}$ occurred in both spring and autumn at RCEES (Figs. 3 and 4), which were in good agreement with previous studies (Fig. 8). The evident elevation of $\mathrm{Ca}^{2+}$ concentrations in spring has been usually ascribed to the frequent dust storms (Zhao et al., 2013b), but there was still no explanation about the extremely high $\mathrm{Ca}^{2+}$ concentrations in autumn (Zhao et al., 2013b; Zhang et al., 2013). The intensive maize harvest and soil ploughing in autumn in the vast agricultural fields of the NCP were suspected to contribute to atmospheric $\mathrm{Ca}^{2+}$ in Beijing. Because abundant atmospheric mineral particles were absorbed by crop leaves (Bealey et al., 2007; Ji et al., 2013) during crop growing season, especially in North China where atmospheric mineral dust is always at a high level (Zhang et al., 2013; Zhao et al., 2013b), a large fraction of the mineral dust absorbed on the leaves of crop could be released into the atmosphere during harvest with crop straw being crushed into pieces for returning to fields which is a prevailing method under the advocacy of governments for reducing the influence of crop straw burning on the air quality. Additionally, the soil ploughing can also cause the suspension of particles (Fang et al., 2006; Chen et al., 2015). The remarkably high concentrations of $\mathrm{Ca}^{2+}$ during the autumn at DBT (Fig. 4) should be ascribed to the above agricultural activities because there are few construction activities in the rural area. Compared with the periods before and after maize harvest and soil ploughing, the proportion of $\mathrm{Ca}^{2+}$ during maize harvest and soil ploughing in autumn increased by about $5-7 \%$ (Fig. 7), confirming the influence of maize harvest and soil ploughing on atmospheric $\mathrm{Ca}^{2+}$ in Beijing. The back trajectory cluster analysis also supported the above conclusion: (1) the extremely high concentrations of $\mathrm{Ca}^{2+}$ in Beijing occurred during the period of 6-25 October (Figs. 3 and 4) when the air parcels were mainly from the southwestsouth regions (Fig. 5) where the vast areas of agricultural 
Table 2. SOR and NOR during haze days and non-haze days in four seasons at RCEES.

\begin{tabular}{|c|c|c|c|c|c|c|c|c|}
\hline & \multicolumn{2}{|c|}{ Spring } & \multicolumn{2}{|c|}{ Summer } & \multicolumn{2}{|c|}{ Autumn } & \multicolumn{2}{|c|}{ Winter } \\
\hline & SOR & NOR & SOR & NOR & SOR & NOR & SOR & NOR \\
\hline Haze days & 0.3 & 0.3 & 0.7 & 0.4 & 0.6 & 0.4 & 0.2 & 0.3 \\
\hline Non-haze days & 0.2 & 0.2 & 0.3 & 0.2 & 0.3 & 0.2 & 0.1 & 0.1 \\
\hline Ratio & 1.8 & 1.8 & 2.0 & 2.3 & 2.0 & 2.6 & 2.3 & 2.5 \\
\hline
\end{tabular}

The ratio of values in haze days to that in non-haze days.

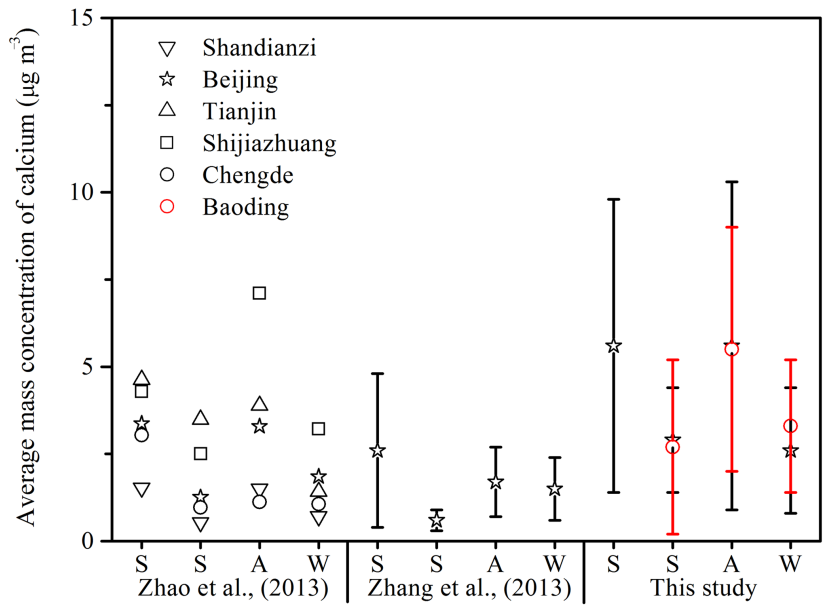

Figure 8. Comparison of average mass concentrations of calcium in four seasons between previous studies and this study for several cities in the NCP $(\mathrm{S}, \mathrm{S}, \mathrm{A}$ and $\mathrm{W}$ represent spring, summer, autumn and winter, respectively. The black symbols represent the urban sites and the red symbol represents the rural site (DBT).).

field were under intensive maize harvest and soil ploughing. (2) Although the concentrations of $\mathrm{Ca}^{2+}$ in the rural area remained at high levels during the period of 2-14 November (Figs. 3 and 4), the relatively low concentrations of $\mathrm{Ca}^{2+}$ in Beijing were observed during the period when the air parcels were mainly from the northwest region (Fig. 5) where agricultural activities are relatively sparse.

\subsubsection{The sources of $\mathrm{NH}_{4}^{+}, \mathrm{SO}_{4}^{2-}$ and $\mathrm{NO}_{3}^{-}$}

The remarkably high concentrations of $\mathrm{NH}_{4}^{+}, \mathrm{SO}_{4}^{2-}$ and $\mathrm{NO}_{3}^{-}$also appeared in both winter and autumn at the two sites (Fig. 4). $\mathrm{NH}_{4}^{+}$was mainly from the reactions of $\mathrm{NH}_{3}$ with acid gases (such as $\mathrm{HNO}_{3}$ ) and acid particles, and hence its variation trend was the same as those of $\mathrm{SO}_{4}^{2-}$ and $\mathrm{NO}_{3}^{-}$. Although atmospheric $\mathrm{NH}_{3}$ has long been considered to be mainly from agricultural activities, their emissions mainly concentrate on warmer seasons (Krupa, 2003), which cannot explain the frequent high concentrations of $\mathrm{NH}_{4}^{+}$observed in winter. Besides the increased gas-to-particle partitioning of ammonium nitrate at lower temperatures, strong $\mathrm{NH}_{3}$ emission sources other than agricultural activities were suspected to be responsible for the frequent high concentrations of $\mathrm{NH}_{4}^{+}$in the cold winter. Besides $\mathrm{NH}_{3}$ emission from vehicles (T. Y. Liu et al., 2014), strong emission of $\mathrm{NH}_{3}$ from farmers' coal stoves (the $\mathrm{NH}_{3}$ emission factor was $0.62-1.10 \mathrm{~g} \mathrm{~kg}^{-1}$ coal) was indeed found by our preliminary measurements, which was in line with the latest study (Li et al., 2016). During the serious pollution episodes, the concentrations of $\mathrm{SO}_{2}$ at RCEES in autumn were almost the same as those in summer and about 1 order of magnitude lower than in winter (Fig. 9), but the peak concentrations of $\mathrm{SO}_{4}^{2-}$ in autumn were about a factor of 2 greater than those in summer and at almost the same level as those in winter. The gaseous phase reaction with OH (Zhao et al., 2013; Quan et al., 2014), the heterogeneous reaction on mineral dust (He et al., 2014; Nie et al., 2014), and multiphase reactions in the aerosol water (B. Zheng et al., 2015) of $\mathrm{SO}_{2}$ have been recognized to be responsible for atmospheric $\mathrm{SO}_{4}^{2-}$ formation. The significant elevation of both $\mathrm{Ca}^{2+}$ and $\mathrm{SO}_{4}^{2-}$ in autumn implied that the heterogeneous reaction of $\mathrm{SO}_{2}$ on the mineral dust might greatly accelerate the conversion of $\mathrm{SO}_{2}$ to $\mathrm{SO}_{4}^{2-}$. Although evidently high concentrations of $\mathrm{Ca}^{2+}$ occurred (Figs. 3 and 4 ) in spring and $\mathrm{SO}_{2}$ concentrations were much greater in spring than in autumn (Fig. 9), the $\mathrm{SO}_{4}^{2-}$ concentrations were about a factor of 2 less in spring than in autumn. Atmospheric humidity was suspected to play an important role in the heterogeneous reaction, e.g. the relative humidity was much higher in autumn than in spring during the serious pollution events (Fig. 9). Similar to $\mathrm{SO}_{4}^{2-}$, the relatively high concentrations of $\mathrm{NO}_{3}^{-}$during the serious pollution events in autumn were also ascribed to the heterogeneous reaction of $\mathrm{NO}_{2}$ on the mineral dust. Therefore, the emission of mineral dust from maize harvest and soil ploughing in autumn also played important roles in secondary formation of nitrate and sulfate in Beijing.

The nitrogen oxidation ratio $\mathrm{NOR}=n \mathrm{NO}_{3}^{-} /\left(n \mathrm{NO}_{3}^{-}\right.$ $+n \mathrm{NO}_{x}$ ) ( $n$ refers to molar concentration) and the sulfur oxidation ratio $\mathrm{SOR}=n \mathrm{SO}_{4}^{2-} /\left(n \mathrm{SO}_{4}^{2-}+n \mathrm{SO}_{2}\right)$ have been used to estimate the degree of secondary formation of $\mathrm{NO}_{3}^{-}$ and $\mathrm{SO}_{4}^{2-}$, which can counteract the interference of meteorological factors (Chan and Yao, 2008; Yu et al., 2013; Guo et al., 2014; R. J. Huang et al., 2014; Y. R. Yang et al., 2015; G. J. Zheng et al., 2015). The values of NOR and SOR during haze days and non-haze days in four seasons are listed 


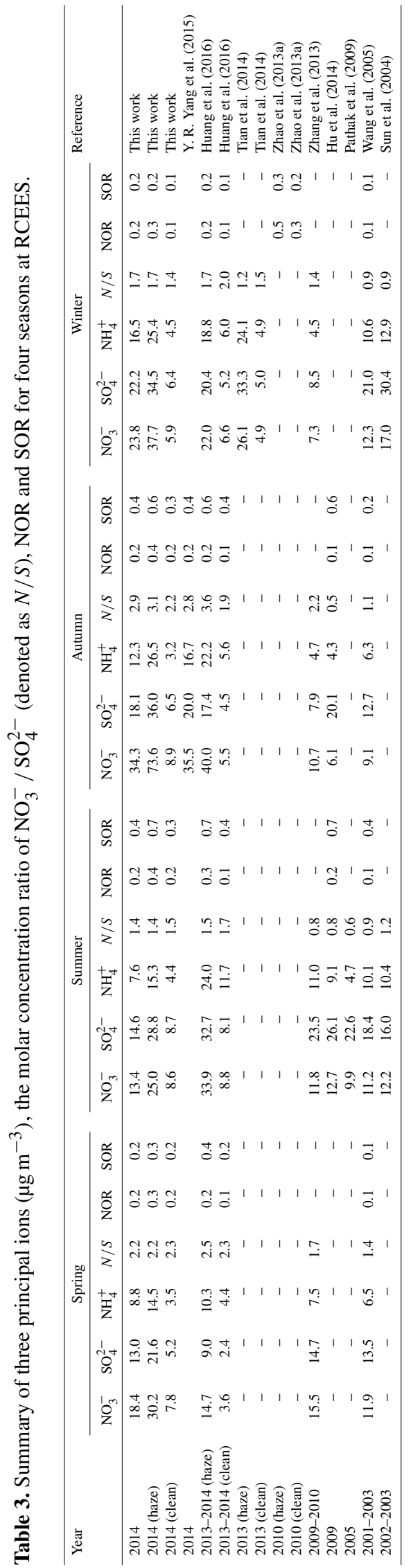

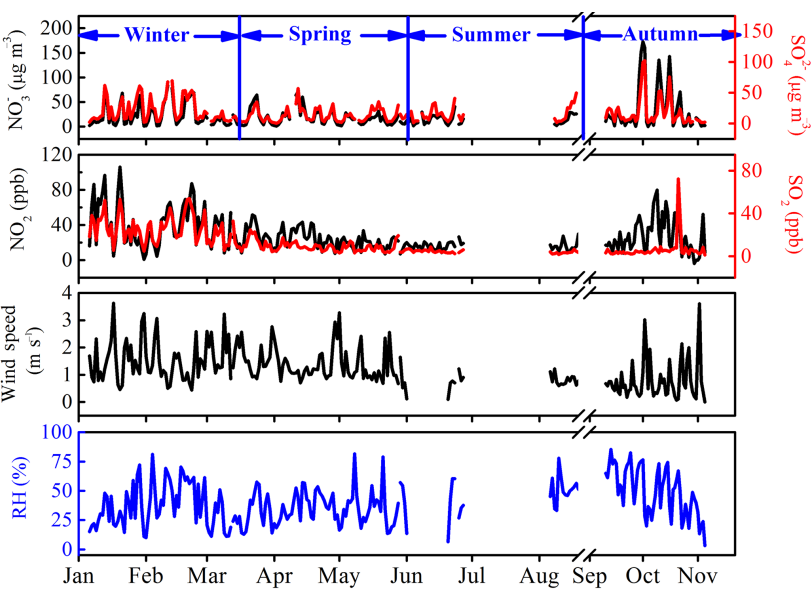

Figure 9. Time series of $\mathrm{NO}_{3}^{-}, \mathrm{SO}_{4}^{2-}, \mathrm{NO}_{2}$ and $\mathrm{SO}_{2}$ and meteorological data (wind speed and relative humidity) during the four seasons in Beijing for 2014.

in Table 2. Both the values of NOR and SOR on non-haze days were found to be the highest in summer and the lowest in winter, reflecting the seasonal variation of photochemical intensity. Although sunlight intensity greatly reduced at ground level during haze days, the values of NOR and SOR were about a factor of 2 greater during haze days than during non-haze days in the four seasons, implying again that the heterogeneous or multiphase reactions of $\mathrm{SO}_{2}$ and $\mathrm{NO}_{2}$ on atmospheric particles made a significant contribution to atmospheric sulfate and nitrate.

\subsubsection{The variation characteristics of $\mathrm{NO}_{3}^{-}$and $\mathrm{SO}_{4}^{2-}$ during serious pollution episodes}

As shown in Fig. 9, the serious pollution episodes with noticeable elevation of various pollutants usually occurred under slow wind speed (less than $2 \mathrm{~m} \mathrm{~s}^{-1}$ ) and high relative humidity. In comparison with their precursors of $\mathrm{SO}_{2}$ and $\mathrm{NO}_{x}$, the detailed variation trends of $\mathrm{SO}_{4}^{2-}$ and $\mathrm{NO}_{3}^{-}$were different, indicating that the elevation of $\mathrm{SO}_{4}^{2-}$ and $\mathrm{NO}_{3}^{-}$was not simply ascribed to the physical process of accumulation. It is interesting to note that the increasing rates of $\mathrm{SO}_{4}^{2-}$ during some serious pollution events especially with elevation of $\mathrm{Ca}^{2+}$ (such as in spring and autumn) were much slower than those of $\mathrm{NO}_{3}^{-}$(Fig. 10), implying that the atmospheric heterogeneous reaction of $\mathrm{NO}_{2}$ on the mineral dust was faster than that of $\mathrm{SO}_{2}$. Compared with summer and winter, the relatively high ratios of $\mathrm{NO}_{3}^{-} / \mathrm{SO}_{4}^{2-}$ in spring and autumn (Fig. 6) also supported the above conclusion.

\subsection{Comparison with previous studies}

The mean concentrations of the three principal ions and some related indicators in Beijing over the past decade are summarized in Table 3. The seasonal variations of the three principal ions reported were quite different, e.g. Huang et al. (2016) 

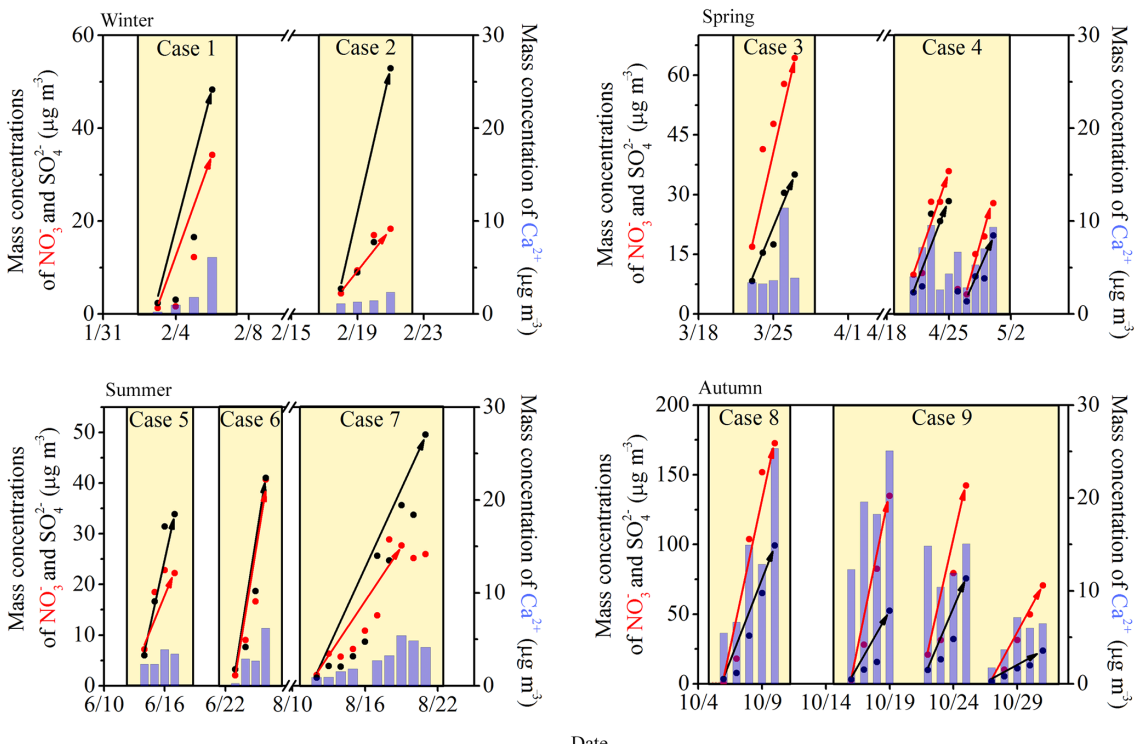

Figure 10. Case studies about the increasing rates of $\mathrm{NO}_{3}^{-}$and $\mathrm{SO}_{4}^{2-}$ with the elevation of $\mathrm{Ca}^{2+}$ during serious pollution events in the four seasons.

found the maximal mean concentrations of $\mathrm{SO}_{4}^{2-}$ and $\mathrm{NH}_{4}^{+}$ in the summer and of $\mathrm{NO}_{3}^{-}$in the autumn of 2014, whereas in this study all the maximal mean concentrations of the three principal ions appeared in autumn. The mean concentrations of the three ions in autumn in this study were in good agreement with the values reported by Yang et al. (2015). For the molar concentration ratios of $\mathrm{NO}_{3}^{-} / \mathrm{SO}_{4}^{2-}($ denoted as $N / S)$, all the investigations exhibited relatively high values in autumn and spring, further confirming that the heterogeneous reaction of $\mathrm{NO}_{2}$ on mineral dust favoured nitrate formation (as discussed above). For NOR and SOR, all investigations were in good agreement, with the highest values in summer, the lowest in winter and higher values during haze days than during clean days. Compared with the investigations of 2003, the evident increase of both the concentration of $\mathrm{NO}_{3}^{-}$and the ratio of $N / S$ in recent years revealed the fast increase of vehicle numbers in the decade made a significant contribution to atmospheric nitrate.

\section{Conclusions}

The large daily fluctuation of the WSIs in each season confirmed that meteorological factors played an important role in governing the accumulation and dispersion of the pollutants. The extremely high concentrations of the WSIs during the serious pollution episodes indicated there were strong sources of the pollutants in Beijing. Based on the comprehensive analysis of the data of the WSIs, the farmers' activities, such as crop harvest, crop straw burning, and coal combustion for heating, were found to contribute to the atmospheric WSIs in Beijing. To mitigate the currently serious pollution status in the NCP including Beijing, greater attention should be paid to the strong emissions of pollutants from the periodic activities of farmers.

\section{Data availability}

All data described here are available upon request from the corresponding author.

Author contributions. Y. J. Mu designed the experiments and prepared the manuscript. P. F. Liu carried out the experiments and prepared the manuscript. C. L. Zhang carried out the experiments. C. T. Liu, C. Y. Xue, C. Ye, J. F. Liu and Y. Y. Zhang were involved in part of the work. H. X. Zhang provided the meteorological data and trace gases.

Acknowledgements. This work was supported by the National Natural Science Foundation of China (21477142, 41203070 and 91544211), the "Strategic Priority Research Program" of the Chinese Academy of Sciences (XDB05010100) and the Special Fund for Environmental Research in the Public Interest (201509002).

Edited by: S. A. Nizkorodov

Reviewed by: three anonymous referees

\section{References}

Bealey, W. J., McDonald, A. G., Nernitz, E., Donovan, R., Dragosits, U., Duffy, T. R., and Fowler, D.: Estimating the re- 
duction of urban $\mathrm{PM}_{10}$ concentrations by trees within an environmental information system for planners, J. Environ. Manage., 85, 44-58, doi:10.1016/j.jenvman.2006.07.007, 2007.

Brewer, P. G. (Eds.): Minor elements in sea water, Chemical Oceanography, Academic, San Diego, California, 1975.

Buseck, P. R. and Posfai, M.: Airborne minerals and related aerosol particles: Effects on climate and the environment, P. Natl. Acad. Sci. USA, 96, 3372-3379, doi:10.1073/pnas.96.7.3372, 1999.

Chan, C. K. and Yao, X.: Air pollution in mega cities in China, Atmos. Environ., 42, 1-42, doi:10.1016/j.atmosenv.2007.09.003, 2008.

Charron, A., Harrison, R. M., Moorcroft, S., and Booker, J.: Quantitative interpretation of divergence between $\mathrm{PM}_{10}$ and $\mathrm{PM}_{2.5}$ mass measurement by TEOM and gravimetric (Partisol) instruments, Atmos. Environ., 38, 415-423, doi:10.1016/j.atmosenv.2003.09.072, 2004.

Chen, Y. J., Sheng, G. Y., Bi, X. H., Feng, Y. L., Mai, B. $\mathrm{X}$., and $\mathrm{Fu}$, J. M.: Emission factors for carbonaceous particles and polycyclic aromatic hydrocarbons from residential coal combustion in China, Environ. Sci. Technol., 39, 1861-1867, doi:10.1021/es0493650, 2005.

Chen, W., Tong, D., Zhang, S., Dan, M., Zhang, X., and Zhao, H.: Temporal variability of atmospheric particulate matter and chemical composition during a growing season at an agricultural site in northeastern China, J. Environ. Sci., 38, 133-141, doi:10.1016/j.jes.2015.05.023, 2015.

Cheng, Y. F., Eichler, H., Wiedensohler, A., Heintzenberg, J., Zhang, Y. H., Hu, M., Herrmann, H., Zeng, L. M., Liu, S., Gnauk, T., Brüggemann, E., and He, L. Y.: Mixing state of elemental carbon and non-light-absorbing aerosol components derived from in situ particle optical properties at Xinken in Pearl River Delta of China, J. Geophys. Res., 111, D20204, doi:10.1029/2005jd006929, 2006.

Christian, T. J., Yokelson, R. J., Cárdenas, B., Molina, L. T., Engling, G., and Hsu, S.-C.: Trace gas and particle emissions from domestic and industrial biofuel use and garbage burning in central Mexico, Atmos. Chem. Phys., 10, 565-584, doi:10.5194/acp10-565-2010, 2010.

Fang, G. C., Wu, Y. S., Chen, J. C., Rau, J. Y., Huang, S. H., and Lin, C. K.: Concentrations of ambient air particulates (TSP, $\mathrm{PM}_{2.5}$ and $\mathrm{PM}_{2.5-10}$ ) and ionic species at offshore areas near Taiwan Strait, J. Hazard. Mater., 132, 269-276, doi:10.1016/j.jhazmat.2005.09.049, 2006.

Finlayson-Pitts, B. J. and Barbara J.: Atmospheric Chemistry, Library of Congress, Canada, 1986.

Finlayson-Pitts, B. J. and Pitts, J. N. (Eds.): Chemistry of the upper and lower atmosphere, Academic Press, San Diego, 2000.

Gao, X., Yang, L., Cheng, S., Gao, R., Zhou, Y., Xue, L., Shou, Y., Wang, J., Wang, X., Nie, W., Xu, P., and Wang, W.: Semicontinuous measurement of water-soluble ions in $\mathrm{PM}_{2.5}$ in Jinan, China: Temporal variations and source apportionments, Atmos. Environ., 45, 6048-6056, doi:10.1016/j.atmosenv.2011.07.041, 2011.

Geng, C., Chen, J., Yang, X., Ren, L., Yin, B., Liu, X., and Bai, Z.: Emission factors of polycyclic aromatic hydrocarbons from domestic coal combustion in China, J. Environ. Sci., 26, 160166, doi:10.1016/s1001-0742(13)60393-9, 2014.

Grover, B. D., Kleinman, M., Eatough, N. L., Eatough, D. J., Hopke, P. K., Long, R. W., Wilson, W. E., Meyer, M. B., and
Ambs, J. L.: Measurement of total $\mathrm{PM}_{2.5}$ mass (nonvolatile plus semivolatile) with the Filter Dynamic Measurement System tapered element oscillating microbalance monitor, J. Geophys. Res., 110, D07S03, doi:10.1029/2004jd004995, 2005.

Guo, S., Hu, M., Guo, Q., Zhang, X., Zheng, M., Zheng, J., Chang, C. C., Schauer, J. J., and Zhang, R.: Primary sources and secondary formation of organic aerosols in Beijing, China, Environ. Sci. Technol., 46, 9846-9853, 10.1021/es2042564, 2012.

Guo, S., Hu, M., Zamora, M. L., Peng, J., Shang, D., Zheng, J., Du, Z., Wu, Z., Shao, M., Zeng, L., Molina, M. J., and Zhang, R.: Elucidating severe urban haze formation in China, P. Natl. Acad. Sci USA, 111, 17373-17378, doi:10.1073/pnas.1419604111, 2014.

He, H., Wang, Y., Ma, Q., Ma, J., Chu, B., Ji, D., Tang, G., Liu, C., Zhang, H., and Hao, J.: Mineral dust and $\mathrm{NO}_{x}$ promote the conversion of $\mathrm{SO}_{2}$ to sulfate in heavy pollution days, Scientific Reports, 4, 4172, doi:10.1038/srep04172, 2014.

Hu, G., Zhang, Y., Sun, J., Zhang, L., Shen, X., Lin, W., and Yang, Y.: Variability, formation and acidity of water-soluble ions in $\mathrm{PM}_{2.5}$ in Beijing based on the semi-continuous observations, Atmos. Res., 145-146, 1-11, doi:10.1016/j.atmosres.2014.03.014, 2014.

Huang, R. J., Zhang, Y., Bozzetti, C., Ho, K. F., Cao, J. J., Han, Y., Daellenbach, K. R., Slowik, J. G., Platt, S. M., Canonaco, F., Zotter, P., Wolf, R., Pieber, S. M., Bruns, E. A., Crippa, M., Ciarelli, G., Piazzalunga, A., Schwikowski, M., Abbaszade, G., SchnelleKreis, J., Zimmermann, R., An, Z., Szidat, S., Baltensperger, U., El Haddad, I., and Prevot, A. S.: High secondary aerosol contribution to particulate pollution during haze events in China, Nature, 514, 218-222, doi:10.1038/nature13774, 2014.

Huang, W., Bi, X., Zhang, G., Huang, B., Lin, Q., Wang, X., Sheng, G., and Fu, J.: The chemical composition and stable carbon isotope characteristics of particulate matter from the residential honeycomb coal briquettes combustion, Geochimica, 43, 640-640, 2014.

Huang, X., Song, Y., Li, M., Li, J., and Zhu, T.: Harvest season, high polluted season in East China, Environ. Res. Lett., 7, 044033, doi:10.1088/1748-9326/7/4/044033, 2012.

Huang, X., Liu, Z., Zhang, J., Wen, T., Ji, D., and Wang, Y.: Seasonal variation and secondary formation of sizesegregated aerosol water-soluble inorganic ions during pollution episodes in Beijing, Atmos. Res., 168, 70-79, doi:10.1016/j.atmosres.2015.08.021, 2016.

Ji, J., Wang, G., Du, X., Jin, C., Yang, H., Liu, J., Yang, Q., Tchouopou Lontchi, J., Li, J., and Chang, C.: Evaluation of Adsorbing Haze $\mathrm{PM}_{2.5}$ Fine Particulate Matters with Plants in Beijing-Tianjin-Hebei Region in China, Scientia Sinica Vitae, 43, 694-699, 2013.

Jiang, Q., Sun, Y. L., Wang, Z., and Yin, Y.: Aerosol composition and sources during the Chinese Spring Festival: fireworks, secondary aerosol, and holiday effects, Atmos. Chem. Phys., 15, 6023-6034, doi:10.5194/acp-15-6023-2015, 2015.

Kong, S. F., Li, L., Li, X. X., Yin, Y., Chen, K., Liu, D. T., Yuan, L., Zhang, Y. J., Shan, Y. P., and Ji, Y. Q.: The impacts of firework burning at the Chinese Spring Festival on air quality: insights of tracers, source evolution and aging processes, Atmos. Chem. Phys., 15, 2167-2184, doi:10.5194/acp-15-2167-2015, 2015.

Krupa, S. V.: Effects of atmospheric ammonia $\left(\mathrm{NH}_{3}\right)$ on terrestrial vegetation: a review, Environ. Pollut., 124, 179-221, doi:10.1016/s0269-7491(02)00434-7, 2003. 
Li, J., Song, Y., Mao, Y., Mao, Z., Wu, Y., Li, M., Huang, X., $\mathrm{He}, \mathrm{Q}$., and $\mathrm{Hu}, \mathrm{M} .:$ Chemical characteristics and source apportionment of $\mathrm{PM}_{2.5}$ during the harvest season in eastern China's agricultural regions, Atmos. Environ., 92, 442-448, doi:10.1016/j.atmosenv.2014.04.058, 2014.

Li, Q., Jiang, J. K., Cai, S. Y., Zhou, W., Wang, S. X., Duan, L., and Hao, J. M.: Gaseous Ammonia Emissions from Coal and Biomass Combustion in Household Stoves with Different Combustion Efficiencies, Environ. Sci. Tech. Lett., 3, 98-103, doi:10.1021/acs.estlett.6b00013, 2016.

Li, W., Zhou, S., Wang, X., Xu, Z., Yuan, C., Yu, Y., Zhang, Q., and Wang, W.: Integrated evaluation of aerosols from regional brown hazes over northern China in winter: Concentrations, sources, transformation, and mixing states, J. Geophys. Res., 116, D09301, doi:10.1029/2010jd015099, 2011.

Li, X., Wang, L., Ji, D., Wen, T., Pan, Y., Sun, Y., and Wang, Y.: Characterization of the size-segregated water-soluble inorganic ions in the Jing-Jin-Ji urban agglomeration: Spatial/temporal variability, size distribution and sources, Atmos. Environ., 77, 250-259, doi:10.1016/j.atmosenv.2013.03.042, 2013.

Liang, C. S., Duan, F. K., He, K. B., and Ma, Y. L.: Review on recent progress in observations, source identifications and countermeasures of $\mathrm{PM}_{2.5}$, Environ. Int., 86, 150-170, doi:10.1016/j.envint.2015.10.016, 2016.

Liu, C. N., Lin, S. F., Awasthi, A., Tsai, C. J., Wu, Y. C., and Chen, C. F.: Sampling and conditioning artifacts of $\mathrm{PM}_{2.5}$ in filter-based samplers, Atmos. Environ., 85, 48-53, doi:10.1016/j.atmosenv.2013.11.075, 2014.

Liu, T. Y., Wang, X. M., Wang, B. G., Ding, X., Deng, W., Lu, S. J., and Zhang, Y. L.: Emission factor of ammonia $\left(\mathrm{NH}_{3}\right)$ from on-road vehicles in China: tunnel tests in urban Guangzhou, Environ. Res. Lett., 9, 064027, doi:10.1088/1748-9326/9/6/064027, 2014.

Liu, X. G., Li, J., Qu, Y., Han, T., Hou, L., Gu, J., Chen, C., Yang, Y., Liu, X., Yang, T., Zhang, Y., Tian, H., and Hu, M.: Formation and evolution mechanism of regional haze: a case study in the megacity Beijing, China, Atmos. Chem. Phys., 13, 4501-4514, doi:10.5194/acp-13-4501-2013, 2013.

Ma, Z., Liang, Y., Zhang, J., Zhang, D., Shi, A., Hu, J., Lin, A., Feng, Y., Hu, Y., and Liu, B.: $\mathrm{PM}_{2.5}$ profiles of typical sources in Beijing, Acta Scientiae Circumstantiae, 35, 4043-4052, 2015.

Nel, A.: Air pollution-related illness: Effects of particles, Science, 308, 804-806, doi:10.1126/science.1108752, 2005.

Nie, W., Ding, A., Wang, T., Kerminen, V. M., George, C., Xue, L., Wang, W., Zhang, Q., Petaja, T., Qi, X., Gao, X., Wang, X., Yang, X., Fu, C., and Kulmala, M.: Polluted dust promotes new particle formation and growth, Scientific reports, 4, 6634, doi:10.1038/srep06634, 2014.

Pang, X. B. and Mu, Y. J.: Seasonal and diurnal variations of carbonyl compounds in Beijing ambient air, Atmos. Environ., 40, 6313-6320, doi:10.1016/j.atmosenv.2006.05.044, 2006.

Pathak, R. K., Wu, W. S., and Wang, T.: Summertime $\mathrm{PM}_{2.5}$ ionic species in four major cities of China: nitrate formation in an ammonia-deficient atmosphere, Atmos. Chem. Phys., 9, 17111722, doi:10.5194/acp-9-1711-2009, 2009.

Peplow, M.: Beijing smog contains witches' brew of microbes, Nature, 10, doi:10.1038/nature.2014.14640, 2014.
Pöschl, U.: Atmospheric aerosols: composition, transformation, climate and health effects, Angew. Chem. Int. Ed. Engl., 44, 75207540, doi:10.1002/anie.200501122, 2005.

Quan, J., Tie, X., Zhang, Q., Liu, Q., Li, X., Gao, Y., and Zhao, D.: Characteristics of heavy aerosol pollution during the 20122013 winter in Beijing, China, Atmos. Environ., 88, 83-89, doi:10.1016/j.atmosenv.2014.01.058, 2014.

Revuelta, C. C., de la Fuente Santiago, E., and Vázquez, J. A. R.: Characterization of Polycyclic Aromatic Hydrocarbons in Emissions from Coal-Fired Power Plants: The Influence of Operation Parameters, Environ. Technol., 20, 61-68, doi:10.1080/09593332008616793, 1999.

Seinfeld, J. H. and Pandis, S. N.: Atmospheric chemistry and physics, Wiley, New York, 1998.

Shen, Z., Cao, J., Arimoto, R., Han, Z., Zhang, R., Han, Y., Liu, S., Okuda, T., Nakao, S., and Tanaka, S.: Ionic composition of TSP and $\mathrm{PM}_{2.5}$ during dust storms and air pollution episodes at Xi' an, China, Atmos. Environ., 43, 2911-2918, doi:10.1016/j.atmosenv.2009.03.005, 2009.

Sun, Y., Zhuang, G., Tang, A., Wang, Y., and An, Z.: Chemical Characteristics of $\mathrm{PM}_{2.5}$ and $\mathrm{PM}_{10}$ in Haze-Fog Episodes in Beijing, Environ. Sci. Technol., 40, 3148-3155, 2006.

Sun, Y. L., Zhuang, G. S., Ying, W., Han, L. H., Guo, J. H., Mo, D., Zhang, W. J., Wang, Z. F., and Hao, Z. P.: The airborne particulate pollution in Beijing - concentration, composition, distribution and sources, Atmos. Environ., 38, 5991-6004, doi:10.1016/j.atmosenv.2004.07.009, 2004.

Sun, Y. L., Wang, Z. F., Fu, P. Q., Yang, T., Jiang, Q., Dong, H. B., Li, J., and Jia, J. J.: Aerosol composition, sources and processes during wintertime in Beijing, China, Atmos. Chem. Phys., 13, 4577-4592, doi:10.5194/acp-13-4577-2013, 2013.

Tham, Y. J., Wang, Z., Li, Q., Yun, H., Wang, W., Wang, X., Xue, L., Lu, K., Ma, N., Bohn, B., Li, X., Kecorius, S., Größ, J., Shao, M., Wiedensohler, A., Zhang, Y., and Wang, T.: Significant concentrations of nitryl chloride sustained in the morning: Investigations of the causes and impacts on ozone production in a polluted region of northern China, Atmos. Chem. Phys. Discuss., doi:10.5194/acp-2016-439, in review, 2016.

Tian, S., Pan, Y., Liu, Z., Wen, T., and Wang, Y.: Size-resolved aerosol chemical analysis of extreme haze pollution events during early 2013 in urban Beijing, China, J. Hazard. Mater., 279, 452-460, doi:10.1016/j.jhazmat.2014.07.023, 2014.

Wang, G., Cheng, S., Li, J., Lang, J., Wen, W., Yang, X., and Tian, L.: Source apportionment and seasonal variation of $\mathrm{PM}_{2.5}$ carbonaceous aerosol in the Beijing-Tianjin-Hebei region of China, Environ. Monit. Assess., 187, 143, doi:10.1007/s10661015-4288-x, 2015.

Wang, H., Tan, S. C., Wang, Y., Jiang, C., Shi, G. Y., Zhang, M. X., and Che, H. Z.: A multisource observation study of the severe prolonged regional haze episode over eastern China in January 2013, Atmos. Environ., 89, 807-815, doi:10.1016/j.atmosenv.2014.03.004, 2014.

Wang, Y., Zhuang, G. S., Tang, A. H., Yuan, H., Sun, Y. L., Chen, S. A., and Zheng, A. H.: The ion chemistry and the source of $\mathrm{PM}_{2.5}$ aerosol in Beijing, Atmos. Environ., 39, 3771-3784, doi:10.1016/j.atmosenv.2005.03.013, 2005.

Wang, Y., Yao, L., Wang, L., Liu, Z., Ji, D., Tang, G., Zhang, J., Sun, Y., Hu, B., and Xin, J.: Mechanism for the formation of the January 2013 heavy haze pollution episode over central 
and eastern China, Science China Earth Sciences, 57, 14-25, 10.1007/s11430-013-4773-4, 2013.

Wu, S., Deng, F., Wei, H., Huang, J., Wang, X., Hao, Y., Zheng, C., Qin, Y., Lv, H., Shima, M., and Guo, X.: Association of cardiopulmonary health effects with source-appointed ambient fine particulate in Beijing, China: a combined analysis from the Healthy Volunteer Natural Relocation (HVNR) study, Environ. Sci. Technol., 48, 3438-3448, doi:10.1021/es404778w, 2014.

$\mathrm{Xu}, \mathrm{S}$. S., Liu, W. X., and Tao, S.: Emission of polycyclic aromatic hydrocarbons in China, Environ. Sci. Technol., 40, 702708, doi:10.1021/es0517062, 2006.

Yang, X., Geng, C., Sun, X., Yang, W., Wang, X., and Chen, J.: Characteristics of particulate-bound polycyclic aromatic hydrocarbons emitted from industrial grade biomass boilers, J. Environ. Sci. (China), 40, 28-34, doi:10.1016/j.jes.2015.09.010, 2016.

Yang, Y., Zhou, R., Wu, J., Yu, Y., Ma, Z., Zhang, L., and Di, Y.: Seasonal variations and size distributions of water-soluble ions in atmospheric aerosols in Beijing, 2012, J. Environ. Sci. (China), 34, 197-205, doi:10.1016/j.jes.2015.01.025, 2015.

Yang, Y. R., Liu, X. G., Qu, Y., An, J. L., Jiang, R., Zhang, Y. H., Sun, Y. L., Wu, Z. J., Zhang, F., Xu, W. Q., and Ma, Q. X.: Characteristics and formation mechanism of continuous hazes in China: a case study during the autumn of 2014 in the North China Plain, Atmos. Chem. Phys., 15, 8165-8178, doi:10.5194/acp-158165-2015, 2015.

Yu, L. D., Wang, G. F., Zhang, R. J., Zhang, L. M., Song, Y., Wu, B. B., Li, X. F., An, K., and Chu, J. H.: Characterization and Source Apportionment of $\mathrm{PM}_{2.5}$ in an Urban Environment in Beijing, Aerosol Air Qual. Res., 13, 574-583, doi:10.4209/aaqr.2012.07.0192, 2013

Zhang, J. K., Sun, Y., Liu, Z. R., Ji, D. S., Hu, B., Liu, Q., and Wang, Y. S.: Characterization of submicron aerosols during a month of serious pollution in Beijing, 2013, Atmos. Chem. Phys., 14, 2887-2903, doi:10.5194/acp-14-2887-2014, 2014.

Zhang, L., Wang, T., Lv, M., and Zhang, Q.: On the severe haze in Beijing during January 2013: Unraveling the effects of meteorological anomalies with WRF-Chem, Atmos. Environ., 104, 11-21, doi:10.1016/j.atmosenv.2015.01.001, 2015.

Zhang, R., Jing, J., Tao, J., Hsu, S.-C., Wang, G., Cao, J., Lee, C. S. L., Zhu, L., Chen, Z., Zhao, Y., and Shen, Z.: Chemical characterization and source apportionment of $\mathrm{PM}_{2.5}$ in Beijing: seasonal perspective, Atmos. Chem. Phys., 13, 7053-7074, doi:10.5194/acp-13-7053-2013, 2013.
Zhang, Y., Schauer, J. J., Zhang, Y., Zeng, L., Wei, Y., Liu, Y., and Shao, M.: Characteristics of particulate carbon emissions from real-world Chinese coal combustion, Environ. Sci. Technol., 42, 5068-5073, doi:10.1021/es7022576, 2008.

Zhang, Y., Liu, J., Mu, Y., Pei, S., Lun, X., and Chai, F.: Emissions of nitrous oxide, nitrogen oxides and ammonia from a maize field in the North China Plain, Atmos. Environ., 45, 2956-2961, doi:10.1016/j.atmosenv.2010.10.052, 2011.

Zhang, Y.-L., Huang, R.-J., El Haddad, I., Ho, K.-F., Cao, J.-J., Han, Y., Zotter, P., Bozzetti, C., Daellenbach, K. R., Canonaco, F., Slowik, J. G., Salazar, G., Schwikowski, M., Schnelle-Kreis, J., Abbaszade, G., Zimmermann, R., Baltensperger, U., Prévôt, A. S. H., and Szidat, S.: Fossil vs. non-fossil sources of fine carbonaceous aerosols in four Chinese cities during the extreme winter haze episode of 2013, Atmos. Chem. Phys., 15, 1299-1312, doi:10.5194/acp-15-1299-2015, 2015.

Zhao, P. S., Dong, F., He, D., Zhao, X. J., Zhang, X. L., Zhang, W. Z., Yao, Q., and Liu, H. Y.: Characteristics of concentrations and chemical compositions for $\mathrm{PM}_{2.5}$ in the region of Beijing, Tianjin, and Hebei, China, Atmos. Chem. Phys., 13, 4631-4644, doi:10.5194/acp-13-4631-2013, 2013a.

Zhao, P. S., Dong, F., Yang, Y. D., He, D., Zhao, X. J., Zhang, W. Z., Yao, Q., and Liu, H. Y.: Characteristics of carbonaceous aerosol in the region of Beijing, Tianjin, and Hebei, China, Atmos. Environ., 71, 389-398, doi:10.1016/j.atmosenv.2013.02.010, 2013b.

Zhao, X. J., Zhao, P. S., Xu, J., Meng,, W., Pu, W. W., Dong, F., He, D., and Shi, Q. F.: Analysis of a winter regional haze event and its formation mechanism in the North China Plain, Atmos. Chem. Phys., 13, 5685-5696, doi:10.5194/acp-13-5685-2013, 2013

Zheng, B., Zhang, Q., Zhang, Y., He, K. B., Wang, K., Zheng, G. J., Duan, F. K., Ma, Y. L., and Kimoto, T.: Heterogeneous chemistry: a mechanism missing in current models to explain secondary inorganic aerosol formation during the January 2013 haze episode in North China, Atmos. Chem. Phys., 15, 2031-2049, doi:10.5194/acp-15-2031-2015, 2015.

Zheng, G. J., Duan, F. K., Su, H., Ma, Y. L., Cheng, Y., Zheng, B., Zhang, Q., Huang, T., Kimoto, T., Chang, D., Pöschl, U., Cheng, Y. F., and He, K. B.: Exploring the severe winter haze in Beijing: the impact of synoptic weather, regional transport and heterogeneous reactions, Atmos. Chem. Phys., 15, 2969-2983, doi:10.5194/acp-15-2969-2015, 2015. 